\title{
An Insight into Violence against Women as Human Rights Violation in Nigeria: A Critique
}

\author{
Ine Nnadi ${ }^{1}$ \\ ${ }^{1}$ Faculty of law, Imo State University, Owerri, Nigeria \\ Correspondence: Ine Nnadi, Faculty of Law, Imo State University, P.M.B. 2000, Owerri, Nigeria. Tel: \\ 23-4-803-325-0809. E-mail: address.inennadi2@yahoo.com
}

Received: June 26, 2012 Accepted: July 24, 2012 Online Published: August 21, 2012

doi:10.5539/jpl.v5n3p48 URL: http://dx.doi.org/10.5539/jpl.v5n3p48

\begin{abstract}
Violence against women is a worldwide malaise, eating deep into the fabric of society. It has become common to see women violated in different aspects of life by their male counterparts, be it their fathers, brothers, husbands or for that matter total strangers. Unfortunately women bear the brunt of a lot of violence in our society and silently cover them up so as to avoid stigmatization or protect their families. In recent times in Nigeria, there have been several cases of violence against women and, most of these cases are kept silent despite their pervasiveness. Issues like sexual harassment, trafficking in women and girls, sex selection, early marriage, female genital mutilation etc are fast becoming epidemics plaguing Nigeria as it is the case globally. This situation is unabatting globally and has elicited public outcry leading to the intervention of the United Nations General Assembly as well as member states coming out with several treaties, laws and policies on women in a bid to protecting the woman from the dehumanizing violation of human rights. This work among other issues examined violence against women and its diverse ramifications and exposed the fact that it is a human rights violation that must be stopped. It also assessed some of the legal regimes relating to violence and found that these regimes have not had their desired impact due to various reasons in Nigeria including the fact that the causes of violence are embedded in unequal power relations between men and women hinged on patriarchal leanings of society and made some recommendations geared at combating the challenge of violence against women.
\end{abstract}

Keywords: violence against women, human rights, violation, dehumanizing, degrading acts, pervasiveness, public outcry, United Nations

\section{Introduction}

Violence against women is a phenomenon that is common in many societies of the world. The subordination of women from birth, knows no barriers in every segment of the life of women whether educated, uneducated, rich or poor. Gender inequality is experienced by women and is manifested in almost all aspects of human endeavor in Nigeria. (Olateru Olagbegi B., 2011) The truth is that violence against women is one of the most ubiquitous violations of women's human rights. This menace involves physical, economic, psychological, social and sexual abuse, and affects all strata irrespective of age, race, culture or status. In acknowledgement of the very pervasive nature of violence against women, the United Nations General Assembly on $25^{\text {th }}$ November 1999, set aside $25^{\text {th }}$ November every year as the international day for the elimination of violence against women.

In addition, the campaign titled "Unite to End Violence against Women" was launched as well as declaration of "16 days of activism against violence against women" every year. It is obvious that in recent times there have been several outcries on the prevalence of violence against women and girls globally and in particular Nigeria. Despite the efforts of the United Nations General Assembly and all the conventions of the United Nations on the issue, with several countries that are signatories to those instruments, yet much has not been achieved in the area of elimination of this canker worm. Even the domestic laws of countries geared towards elimination have not had the desired impact.

What is more, violence against women ranging from diverse acts of discrimination to physical violence has gone on over the decades unabated in spite of the several women's rights movements, the Beijing Platform for Action and the Commission on the Status of Women and other human rights groups in the vanguard against violence. Not surprising therefore the general concern and outcry in support of justice to women generally. 
The truth is that living free from violence is a human right, yet millions of women and girls suffer disproportionately from violence both in peace and in war, at the hands of the state, in the home and community. Across the globe, women are beaten, raped, mutilated, and killed with impunity (WHO, 2011). In Nigeria the Constitution has provisions dealing with equality under the law and also assures the rights to protection from inhuman and degrading treatment in its fundamental human rights provisions. Unfortunately, despite the availability of the constitutional provisions in Nigeria, women are still affected by various forms of violence contrary to the equality guaranteed by the Constitution and various International Instruments. The fact is, the problem of violence against women in Nigeria is rooted in the traditional patriarchal leanings of the society amongst other facts. Usually men were recognized in traditional Nigerian society as superior to women, husbands had a right to chastise their wives and women were subordinate to men within the family.

\section{Meaning of Violence against Women}

Gender-based violence is abuse that is meted on individuals by virtue of their gender. Violence in common language is indicative of great roughness and force often causing severe physical injury or damage (Hornby, 1997). Violence can also be the unlawful use of force or threat to use force on a fellow human being. It is any action, behavior, attitude against people based on anger, frustration, stress, power, ego or even ignorance which could lead to injury, harm, disability or even death.

On their part, Professor Elizabeth Abama and Chris M. A. Kwaja, writing on Violence against Women said: violence against women is a prevalent harm to the basic rights, freedoms, health and welfare of women. It occurs in many settings and at many hands, including those of relatives, acquaintances, employers and the state. In fact, most forms of violence directed specifically against women in Nigeria are met with silence not only by the state but also by much of the human rights community (Note 1).

The UN Women (2011) also observed that, violence against women and girls is one of the most widespread violations of human rights, which includes physical, sexual, psychological, and economic abuse and cuts across boundaries of age, race, culture, wealth, and geography.

Writing on the subject, Violence against Women in the Nigerian Community: Issues of Power and Control, Uchenna Nworah said: Violence against women or gender-based violence is an age-long psycho-social issue, deep-rooted in world societies: developed, developing or third world countries (Nworah, 2010). Violence against women which is also known as gender- based violence according to Andrew Commins in Kenya is (Commins, 2010): an endemic but culturally sensitive outrage perpetrated against women by both private individuals and state actors.

It is noteworthy that all acts against a woman are not necessarily gender-based violence, neither are all victims of gender-based violence are women. There are situations where men are victims of sexual violence and also where men are beaten or killed by women in acts of violence.

Similarly, the Declaration on the Elimination of Violence against Women (Resolution 48/104) states that: violence against women is a "Manifestation of historically unequal power relations between men and women, which has led to domination over and, discrimination against women by men and to the prevention of the full advancement of women".

This definition gives an insight into what was prevalent in society in the beginning of creation where women were seen not to be equal to their male counterparts and this notion was firmly held even up to the Roman era. It is to be noted that because violence is not only physical, it could mean with reference to a woman or girl, the use or display of excessive physical emotions towards her which she resents.

In her views Florence Tercier (2011), a former women and war adviser at the International Committee of the Red Cross opines that (ICRC): Violence against women is about "where the power lies." She argued that women, who are already marginalized in peacetime, will be victims at times of hostilities. (Note 2)

In discussing Mainstreaming Reproductive Health and Rights into Legal Education in Nigeria, Aniekwu Nkolika Ijeoma (2006) observed thus:

Violence against women is one of the physical consequences of the economic, social, political and cultural inequalities that exist between men and women. It is perpetrated by legal and cultural systems that have historically discriminated against women.

From the numerous and varied perceptions adumbrated above, it is obvious that each view was coloured by the definer's perspective of the subject. Some of the definitions were very inclusive, explicit, and encapsulate the subject of violence against women as pervasive the world over. 


\section{Overview of Violence against Women}

Violence against women is an age-long vice, existence of which is rooted in antiquity, it has existed from the beginning of creation and has remained unabated to this time despite all efforts to eliminate this obnoxious act. In support of this view Evelyn Lee (2003) observed: I can just say that the problem itself is not a new one. Even though we have been writing on it for a long time it is probably as old as mankind when we think of cave men with their clothes dragging women by their hair from the cave.

Violence against women is prevalent in all corners of the world and it is a human rights violation that manifests itself in several ways, including:

\subsection{Domestic/Intimate Partner Violence}

Violence against women takes a variety of forms, all of which are violations of the fundamental rights of women as in most cases, it debases the woman. However the most common violence experienced by women and girls globally and particularly in Nigeria from birth is domestic violence. This form of violence involves battering and other aspects of intimate partner violence like marital rape, sexual violence, threats, etc.

Domestic violence is an abuse in the family or home perpetrated by a husband, a boyfriend, a brother or any other relative against a woman or girl, such abuse will include, physical, psychological or economic abuse intended to harm, intimidate or coerce the woman to submission. Domestic violence occurs in situations where a family member or an intimate partner, physically, sexually or psychologically dominates the woman or inflicts violence on the woman.

Professor E. N. U. Uzodike (1997), defined violence as:

The application of brutal force to another person in a situation where it is absolutely uncalled for, if it occurs within the privacy of the home it becomes domestic violence.

The Innocenti Digest (2000), writing on Domestic Violence, defines domestic violence as including:

Violence against women and girls by an intimate partner including a cohabiting partner and by other family members, wherever this violence takes place and in whatever form.

In Nigeria violence within the home on both wives and children has cultural backing. Beating women and girls is a permitted form of disciplining them with a restraint not to inflict grievous harm. The provision of the Penal Code (PC) (criminal law applicable in the Northern part of Nigeria specifically encourages violence against women. under its provisions, the beating of a wife for the purpose of correction is provided for (Section 55 (1) (d) of the Penal Code).

Domestic violence in most cases is perpetrated by a father, husband, boyfriend, father in-law, stepfather, brother, uncle, son or other male relation in the home. This sort of violence inflicted on the woman or girl is not discriminatory on grounds of age, class, or even social status, for a woman whatever her station in life and however old she may be, can be subjected to domestic violence by her partner, brother or other male relative. Women can also be violent, but their actions are negligible and account for a small percentage of domestic violence (UNICEF, 2000).

All over the world, it has been estimated that, at least one in every four women suffers domestic violence from the hands of those who claim to either love or protect them (Tribune, 2010). The pathetic thing about domestic violence is that, because it happens in the confines of the home, most of the time women who are victims are silent about the abuse and invariably the violation of their rights, reason for this is attributable to societal response as well as protection of the family members who inflicted the violence. As a matter of fact, domestic violence is so entrenched in the society that some violated women see such acts of beating as a sign of love from the men violating them.

Reports reveal that in Nigeria the level of domestic violence is shockingly high despite the fact that, there is gross under reporting and improper documentation of the incidence of domestic violence in Nigeria. In 2010 in Nigeria, the Deji of Akure publicly beat his wife and was subsequently deposed by the State Government. According to African Examiner Online Police Authorities interrogated the Deji of Akure Oba Oluwadare Adesina over his public fight with his wife Olori Bolanle who was thereafter hospitalized after a substance believed to be acid was sprayed on her (African Examiner online, 2011).

The pervasiveness of domestic violence led to Gloria Egbuji, the Executive Director of Crime Victims Foundation, a non-profit crime victims' outfit in Lagos, to call on the government to take urgent measures to stop the increasing cases of domestic violence against women in the country. Egbuji made the call following the arrest of a middle age man, Sylvester Emezi, by the police for allegedly inflicting injuries on his fiancé's right 
eye. In anger, Emezi allegedly picked up a sharp object and pierced his wife Igho's right eye when the duo had a quarrel over domestic issues. (Note 3)

Cases of domestic violence against women have been on the increase in Nigeria. Earlier in the year, Titilayo Arowolo, a 27 -year-old mother of one was gruesomely murdered by her husband. Arowolo was allegedly axed to death by her husband, Kolade, in their Isolo home in Lagos. (Note 4)

\subsection{Sexual Assault}

Nigerian women face various forms of sexual assault daily. Rape, indecent assault, incest, and defilement are some common sexual assaults that women in Nigeria are confronted with. Several provisions abound in both the Criminal Code and the Penal Code against the varied forms of sexual harassment against women. These provisions are however not effectively implemented due to the technicalities and evidential rules in the proof of sexual offences, in addition to women's silence in sexual offences against them so as to avoid stigmatisation and sometimes the protection of perpetrators who are close family members.

Rape is one aspect of sexual assault that has become the order of the day. Women and girls are indiscriminately raped without regard to their dignity and age. The offence of Rape under the Nigerian laws attracts a heavy punishment of life imprisonment and is defined as "having carnal knowledge of or sexual intercourse with a woman or a girl without her consent or under duress." Many rape cases go unreported. Defilement of young girls is also pervasive globally as babies from the cradle are not spared this dehumanizing horror inflicted on women.

\subsection{Child Marriage}

A serious problem of violation of women in Nigeria is child marriage. Very little girls are sent off to men old enough to be their fathers and grandfathers in marriage, and their consent is hardly sought. In most parts of the country, there is no law that streamlines the right age for marriage and the ones that are there, are usually overlooked. Mention must be made here of the intervention of Bauchi State in this regard where child marriage is prevalent. The State enacted a law banning child marriages after the pathetic case of Hauwa Abubakar, a 9 year old girl who was married off to one Mallam Shehu Garuba Kiruwa a 40 year old cattle dealer. This case is instructive here (UN Report, 2001). Her father being indebted to the husband forcefully gave Hauwa as wife to Shehu at the tender age of 9. She ran away from the husband's house on two occasions and was forcefully brought back to his house, on the third occasion; when she ran away and was brought back by her parents, the husband pinned her down and chopped off her legs with a poisoned cutlass. The Government of Bauchi State reacted by enacting a decree empowering Government to prosecute any parent who withdraws a child from school for marriage. It is hoped that other States would follow the bold step taken by Bauchi State and enact laws in this regard.

On this issue also, it is worthy to point out that the 1999 Constitution of the Federal Republic of Nigeria has complicated matters on early marriage, by deeming a child, to be an adult in so far as that child is married. This ambit of the constitution gives credence to violence against girl children contrary to Article 16 of the Convention on the Elimination of All Discrimination against Women (CEDAW), which prohibits the betrothal, and marriage of the girl child.

\subsection{Widowhood Practices}

This is another aspect of harmful traditional practice common in Nigeria that violates the woman. A widow is a married woman who becomes single as a result of the death of her husband. Widowhood practices are those customary rites that a widow is made to undergo on the death of her husband by members of the husband's family or community. Widowhood practices differ from one community to another and are practices that are obnoxious, dehumanizing, and diminish the personality of the woman and violate her human rights. Some widowhood rites include:

i. Being locked up with the corpse for days or hours;

ii. Being forced to sit on the bare floor for the duration of the mourning period;

iii. Isolating the widow from other people for some period;

iv. Shaving the hair on the head, pubic or armpit with unsterilized razor blade, scissors or a piece of glass;

v. Eating meals from dirty unwashed plates;

vi. Denial of right to inherit husband's properties;

vii. Drinking of the water used in washing the corpse of the dead husband to prove her innocence;

viii. Walking to the market bare footed to buy foodstuff without collecting change. 
The list of widowhood practices is almost endless as it varies from community to community but most are common in all areas where widowhood rites are performed.

On the death of the husband, the plight of a widow is made worse by the humiliating widowhood rites she undergoes. The above examples are common in the eastern part of Nigeria. In the case of Mojekwu V Mojekwu (1977), the Court of Appeal decided that the "Oli-ekpe" custom of Nnewi in Anambra State where males and not females inherit the property of their father is unconstitutional. Justice Niki Tobi in a rare exhibition of extreme judicial activism, held the "Oli ekpe" custom to be repugnant to natural justice, equity and good conscience. The judgment represents a shift in judicial attitudes to women's rights issues even though at the Supreme Court, he was heavily criticized for that decision. In Theresa Onwo v Nwafor and 12 Ors (1996), the court had to decide the legality of the appellant's tradition requiring her as a widow to shave her hair. In that case Theresa Onwo was required by custom to shave her hair, an act she rejected on the basis of her religion. She went to court to enforce her fundamental rights. The Court of Appeal held that she had a right to do so and gave judgment in her favor.

\subsection{Female Genital Mutilation}

Female Genital Mutilation is also known as Female Genital cutting, Female Genital circumcision, Female Genital Modification or simply "cutting". It means damage caused to the genital organs of the woman. Medically, female genital mutilation involves three basic types: viz Clitoridectomy: which involves the partial or total removal of the clitoris. Excision: partial or total removal of the clitoris and the labia minora with or without excision of the labia majora (the labia are "the lips" that surround the vagina). Infibulations: narrowing of the virginal opening through the creation of a covering seal, with or without removal of the clitoris.Available records have it that reasons for FGM include a mixture of cultural, religious and social factors which are mostly baseless.

Female circumcision as this act is also referred to, is practiced in 28 African countries on the pretext of cultural tradition or hygiene. Despite the constitutional provision against torture and human dignity, female genital mutilation (FGM) is widespread among various ethnic groups in Nigeria. The common type practiced in Nigeria is called clitoridectomy; this entails the removal of the clitoris and sometimes along with labia majora. It takes place mostly at infancy. It is very commonly practised in Bayelsa State of Nigeria. Female genital mutilation has been banned in several states in Nigeria including, (Cross Rivers, Delta, Edo and Ogun) and Bayelsa. The Nigerian constitution guarantees the rights of all against torture and other forms of inhuman or degrading treatment. The rate of its prevalence in several cultures in Nigeria has led to some States enacting laws for its prohibition. Such laws as The Female Circumcision and Genital Mutilation, (Prohibition) Law of Edo State 1999, The Female Genital Mutilation (prohibition) law of Ogun State 2000 and the Female Genital Mutilation (Prohibition) Law of Bayelsa State 2000 are some efforts by States severely affected by this violence to address the issue.

\subsection{Trafficking in Women and Girls}

Trafficking in women and girls is the contemporary form of violence against women which is very disturbing in Nigeria and other African countries. This trend is growing in width and bounds. In the last decade trafficking in women and children has assumed an alarming rate in Nigeria (Human Trafficking in Nigeria, 2010). Nigeria has become a source, transit and destination country for both internal and external trafficking. In 2003 a new comprehensive law was passed by the Nigerian National assembly and assented to by the President, the Trafficking in Persons (Prohibition) Law Enforcement and Administration Act commonly known as the "NAPTIP Act". The NAPTIP Act among other things established the National Agency for Prohibition of Traffic in Persons and Other Related Matters (NAPTIP), the provisions of the Criminal and Penal codes did not provide adequately for the crime of trafficking in women and children. Section 34 of the Constitution of Nigeria prohibits slavery and torture while Sections 223-225 of the Criminal Code provides for sanctions against whosoever trades in prostitution, facilitate the transport of human being within or outside Nigeria for the purpose of commercial sexual exploitation and make profits for it. The Penal Code also sanctioned this act in Section 278-280, it provides for imprisonment for anyone who buys and sells minors for immoral purposes. Nigeria has also signed the Protocol to prevent, suppress and punish trafficking in persons especially women and girls but is yet to ratify it.

Most of the women and girls trafficked to other parts of Europe are from Edo State of Nigeria. This fact necessitated the passing of a law with stiffer penalties by the Government of Edo State (Criminal Code Law, cap 48). Trafficking in women and girls involves involuntary servitude and is therefore often synonymously referred to as "modern day slavery." This form of violence diminishes the status of women and brings low reputation and international shame to Nigeria. 


\subsection{Violence against Women in Custody}

Women who find themselves in custody often times complain about custodial violence in police cells, prisons, immigration detention centers and other state institutions and these constitute violence perpetrated by the state. Sexual violence, mainly rape that is perpetrated against women in detention is considered to be a particularly egregious violation of the inherent dignity of the woman and of her right to physical integrity and that of all human beings and therefore it is considered to constitute torture. (Note 5)

Okereafor Lloyd (2010), commenting on the Amnesty International report titled, Nigeria: Rape- the Silent Weapon, released in Nigeria as part of its global Stop Violence against Women Campaign report in Nigeria indicated as follows:

The 40 page report identified rape as an endemic problem in Nigeria which persists because of the state's failure to tackle discrimination against women or address the entrenched culture of impunity for human rights violations committed by the police and security forces, for whom rape has become a weapon of intimidation of entire communities especially in the Niger Delta, to protect oil production.

Women in the society continue to face violence at the hands of state agents with impunity whilst in custody. Inappropriate surveillance during showering or when a woman is undressing, strip searches conducted by or in the presence of male officers and verbal sexual harassment is some forms of violence suffered by women in custody. Reports are also available to show huge amounts of control wielded by correctional officers over lives of women in custody through the constant demands for sexual acts in exchange for privileges, goods or basic necessities (Note 6). It is now common to see female inmates getting pregnant in police and prison custodies due to sexual harassment.

\subsection{Acid Burning}

This is another form of violence against women that took the center stage in the 1990s in Nigeria and it is prevalent even today. In some cultures, if a woman turns down a suitor or does not get along with her in-laws far too frequently, she becomes a victim of acid burning. Usually Acid is poured o in her face or on her body with the intention of disfiguring her. The unfortunate aspect of acid burning is the fact that in Nigeria, there is little or no control on the sale of acid to the public or adequate punishment for perpetrators.

\section{Effects of Violence against Women}

Violence against women and girls has extensive consequences, devastating families and communities. In 1994, a World Bank study on ten selected risk factors facing girls and women in this age group, found rape and domestic violence more dangerous than cancer, motor vehicle accidents, war and malaria (UN Women, 2011). Studies also reveal increasing links between violence against women and HIV and AIDS.

It has been observed that most children, who grow up in homes where there is violence, may suffer a range of behavioral and emotional disturbances that can be associated with the perpetration or experiencing of violence later in life. Intimate partner violence has also been associated with higher rates of infant and child mortality and morbidity (e.g. diarrhea disease, malnutrition). One social effect of violence in the area of trafficking in women was separation of children from their families as well as stigmatization of the woman (United Nations, 2006). A woman who had previously been trafficked was always seen as a prostitute and never fully accepted back into the community. It is also common to see children of abused women suffer from inferiority complex and is usually withdrawn from other people. In other situations, a battered woman's family members are drawn into feuds and disagreement with their in-laws and are therefore alienated from them.

Gender-based violence not only violates human rights, but also hampers productivity, reduces human capital and undermines economic growth. A 2003 report from the US Centers for Disease Control and Prevention estimates that the costs of intimate partner violence in the United States alone exceeds US $\$ 5.8$ billion per year: US\$4.1 billion are for direct medical and health care services, while productivity losses account for nearly US\$1.8 billion due to absenteeism (UN Women, 2011).

\section{The Problem of Impunity in Violence against Women}

Perpetrators of violence against women are rarely held accountable for their acts. Women who are victims of gender-based violence often have little recourse because many state agencies like the police and prisons are themselves guilty of gender bias and discriminatory practices. Many women opt not to report cases of violence to authorities because they fear being ostracized and shamed by communities that are too often quick to blame victims of violence for the abuses they have suffered. Some brave women who dare to challenge their abusers or report violence against them are embarrassed with probing questions and ridiculed. The truth is that violence 
against women is so deeply embedded in society that it often fails to garner public criticism and outrage particularly as it is clothed with religious immunity in certain cases.

\section{The Way Forward}

Several countries have made some progress in tacking violence against women and girls. However, in some other countries, gaps remain. UN Women works on several fronts towards ending violence against women and girls. In addition, other international and domestic instruments have however been put in place to check discrimination and invariably violence against women.

a. The Universal Declaration of Human Rights (UDHR, 1948) states that "everyone is entitled to all the rights and freedoms set forth in this Declaration, without distinction of any kind, such as race, color, sex, language, religion, political or other opinion, national or social origin, property, birth or other status." (Note 7)

b. The Declaration on the Elimination of Violence Against Women on its part states that "violence against women means any act of gender-based violence that results in, or is likely to result in, physical, sexual or psychological harm or suffering to women, including threats of such acts, coercion or arbitrary deprivation of liberty, whether occurring in public or in private life." It further asserts that states have an obligation to " exercise due diligence to prevent, investigate and, in accordance with national legislation, punish acts of violence against women, whether those acts are perpetrated by the State or by private persons" (Note 8).

c. The Convention on the Elimination of all forms of Discrimination Against Women (CEDAW, 1979), defines discrimination against women as any "distinction, exclusion or restriction made on the basis of sex which has the effect or purpose of impairing or nullifying the recognition, enjoyment or exercise by women, irrespective of their marital status, on the basis of equality between men and women, of human rights or fundamental freedoms in the political, economic, social, cultural, civil or any other field."(Note 9)

d. The International Covenant on Civil and Political Rights and the International Covenant on Economic, Social and Cultural Rights are the two covenants that are fallouts of the Universal Declaration of Human Rights which also prohibit violence against women. Both the ICCPR and the ICESCR are relevant and incisive in the protection of women from violence. Interestingly Nigeria has ratified these two covenants but has not domesticated them or incorporated them into its domestic laws. The effect of non-domestication is that no citizen can rely on them by virtue of section 12 of the 1999 Constitution, even though Nigeria is bound by these instruments under international law.

e. Convention for the suppression of The Traffic in Persons and of the Exploitation of the Prostitution of Others is a resolution of the United Nations General Assembly. It was approved by the General Assembly on 2 December 1949 and came into effect on 25 July 1951 with the aim of curbing the violence of prostitution and trafficking in persons. The preamble of this instrument captures the whole picture thus:

Whereas prostitution and the accompanying evil of traffic in persons for the purpose of prostitution are incompatible with the dignity and worth of the human person and endanger the welfare of the individual, the family and the community.

f. The African Charter on Human and Peoples' Rights and the Protocol to the African Charter on Human and Peoples' Rights on the Rights of Women in Africa, also have provisions dealing with discrimination and violence against women. The provisions of the Charter can be construed as conferring very extensive mandate on states to eliminate any form of discrimination against women including practices that constitute violence against women.

Obviously, the continued prevalence of violence against women and girls in the face of several international legal regimes on the issue demonstrates that this pervasive phenomenon of alarming proportions is yet to receive all the necessary attention and resources it actually deserves. What is more, the manner in which rape trials are conducted in Nigeria and the nature of evidence required exposes the woman victim to indignity, and public ridicule.

More so, the requirements of corroboration and penetration to prove rape cases which though are not part of the definition of rape, have been used over the years in several cases and have denied women victims of rape the deserved justice from the law courts. It is therefore suggested that the law needs to be redefined and the Evidence Act amended in that light particularly, the practice of the courts in demanding for corroboration be removed. More so, the decision in Bango v Chado (1998), to the effect that the courts are now interested in doing substantial justice rather than blindly adhering to the rules is highly recommended. It follows that if strict observance of a rule of practice will produce injustice, the court should overlook it and rather do justice in the case. Judicial activism is therefore suggested in cases involving violence against women. In Nigeria the Penal Code of Nigeria which is applicable in the predominantly Muslim northern parts of Nigeria also validates wife 
beating in Section 55(1) which permits a husband to chastise his wife. This law needs to be reformed to protect the rights of the women and conform with modern international best practices.

What is more, Nigerian Government has shown apathy towards violence against women as it has failed to domesticate the CEDAW and other international instruments on violence against women. Government must therefore be alive to its responsibility by domesticating CEDAW in other to afford women its protection. The bill on violence against women currently before the National Assembly should be passed without delay.

\section{Conclusions}

Violence against women is very pervasive and rampant affecting every part of the world and every strata of society irrespective of age, class, color or education. No nation in the world is spared even though the degree of violence varies from one country to the other. As little babies they may be malnourished, sometimes even tortured to death due to male child preference. Many cultures in Nigeria allow child marriage which leads to the girl-child bearing children before her body is fully developed with its attendant consequences. There are cases from all over the world of young girls being frequently sexually abused and defiled, sometimes by very close relatives and those that are supposed to protect them. As women, some females are raped, beaten, injured and disfigured and traumatized through all manner of behavior and practices at some point in their life time. Violence against women is a violation of human rights that cannot be justified by any political, religious, or cultural claim. A global culture of discrimination against women allows violence to occur daily and with impunity. Most customs give prominence to violence against women while certain religions also give impetus to violence against women. This unwholesome act has led to the maiming and in extreme cases killing of very many women even in Nigeria.

This pervasiveness attracted the United Nations, which came out with a plethora of treaties and conventions as well as member States with domestic laws and policies to curb violence against women. It must be said that the problem of violence will not be solved by bare legal pronouncements in the constitution, or by Nigeria signing and ratifying international and domestic treaties alone, the solution in eradicating violence against women is not in the adequacy or inadequacy of the legal regimes with respect to violence. For invariably these laws will not have the desired effect without the social will to conform to the spirit behind the provisions. The fight against acts of violence on women can only be successfully fought if all hands are joined together, with women and men standing side by side on this issue and presenting a united front. Ultimately there must therefore be sustainability of the fight against acts of violence on women by regular education of men through seminars and workshops, exposing the evils of violence against women, combined with gender equality training and community-based initiatives that address gender inequality specifically. We believe that, it is only in doing so that the effort to curb violence against women and invariably the protection of women can be achieved and sustained globally. The truth is that violence against women is the twin brother of discrimination and serves to reinforce it. It is my view that, there must be in addition to law, a total re-orientation of men and women towards attitudinal change on the status of women and girls in society. Nigeria is a country embedded in patriarchy and so it will not be easy to have deep rooted cultural ethos jettisoned easily without systematic and deliberate action. As the United Nations Secretary General, Ban Ki-Moon posited, "there is one universal truth, applicable to all countries, cultures and communities: violence against women is never acceptable, never excusable, never tolerable."

\section{References}

(1977). 7 NWLR, (part 512). pp. 283.

(1996). 6 NWLR, (part 456). pp. 584.

Abama E., \& Kwaja C. M. A. (2011). Violence Against Women in Nigeria: How the Millennium Development Goals Addresses the Challenge. Retrieved August 7, 2011, from http://www.jpanafrican.com/docs/vol3no3 /33violence against.pdf

African Examiner Online. (2011). Domestic Violence, Police Grills Deji of Akure. Retrieved July 25, 2011, from http://www.africanexaminer.com/deji05

Aniekwu, N. I. (2006). Mainstreaming Reproductive Health and Rights into Legal Education. In J. Ezeilo (Ed.), Law, Reproductive Health and Human Rights, (pp. 105-115). Enugu, Nigeria: WACOL.

Commins, A. (2010). A Gender Based Violence in Kenya and State Response. Retrieved March 10, 2010, from http://www.stjohnchambers.co.uk

Criminal Code Law. (1976). Cap 48, Laws of Bendel State as applicable to Edo State.

Hornby, S. (1997). The Oxford Advanced Learners Dictionary of Current English (5th ed.) (pp. 1329). United Kingdom: Oxford University Press. 
Lee, E. (2003). Setting the Agenda, Perspective on Domestic Violence. In LEDAP (Ed.), Domestic violence, zero tolerance, report on network of Nigerian men against domestic violence (pp. 1-6). Lagos.

NICEF. (2000). Domestic Violence against Women (pp. 3). Haly.

Nworah, U. (2006). Violence against Women in the Nigerian Community. Power and Control. Retrieved from http://www.usafricaonline.com/2011/08/06/violence-against-nigerian-violence-by-uche-nworah

Okereafor, L. (2010). Nigerian Government Must Demonstrate a Commitment to Stop Violence against Women. Retrieved from http://www.justice-ng.org

Olateru, O. B. (2007). Actual Women Situation in Nigeria. Retrieved October 12, 2010, from http://www.wildaf .ao.org/ en/spp.php/article46

Penal Code. (2004). In Laws of the Federation of Nigeria (Section 55).

Red Cross Red Crescent. (2011). Out of the Shadows: Challenging Sexual Violence. The Magazine of the International Red Cross and Red Crescent Movement, 1, 4-9.

Safe World International. (2011). Nigerian women urge government intervention in domestic violence. Retrieved from http://www.asafeworldforwomen.org/domestic-violence/dv-africa/dv-nigeria.

UN Women. (2001). United Nations Entity for Gender Equality and the Empowerment of Women. Retrieved June 14, 2011, from http://www.unifem.org/gender_issues/violence_againstwomen

UNESCO. (2006). Human trafficking in Nigeria, root causes and recommendations. Policy Paper Poverty, Series 14.2 (E). http://unesdoc.unesco.org/images /0014 / 00 1478/147844e.pdf

UNIFEM. (2011). Gender Issues Violence against Women. Retrieved June 15, 2011, from $\mathrm{http}: / /$ www.unifem.org/gender_issues/violenceagainstwomen

United Nations Children's Fund. (2000). Innocenti Digest, 6, pp. 2. Florence: Innocenti Research Centre.

United Nations. (2001). Report on Children and Women's Rights in Nigeria: A Wake up Call.

United Nations. (2006). Ending Violence against Women: from Words to Action (pp. 41). New York.

United Nations. (2006). Study of the Secretary General (pp. 60). New York.

United Nations. General Assembly Resolution.

Uzodike, E. N. U. (1997). Protection against Domestic Violence. In I. Agbede (Ed.), Current Legal Themes in Law, (pp. 338-340). University of Lagos.

WHO. (2011). Violence Against Women: Who Media Centre. Retrieved September 1, 2011, from http://www.who.int/mediacentre/factsheets/fs239/en

\section{Notes}

Note 1. Violence Against Women in Nigeria: How the Millennium Development Goals Addresses the Challenge. Retrieved June 14, 2011, from http://www.jpanafrican.com/docs/vol3no3/3.3ViolenceAgainst.pdf

Note 2. Red Cross Red Crescent, Out of the Shadows, Challenging Sexual Violence, The Magazine Of The International Red Cross And Red Crescent Movement, Issue 1. 2011, p 4F

Note 3. Nigerian women urge government intervention in domestic violence. Retrieved October 10, 2011, from $\mathrm{http}$ ://www.asafeworldforwomen.org/domestic-violence/dv-africa/dv-nigeria.html

Note 4. Domestic Violence Involving Skye Bank Staff. Retrieved August 2, 2011, from http://us.mc1137.mail.yahoo.com/mc/welcome?.tm=1312496540\#_pg=showMessage\&sMid=32\&\&filterBy=\&.r and $=932241351 \&$ midIndex $=7 \&$ mid $=1 \_10508 \_$AFy

Note 5. United Nations. (2006). Ending Violence against Women from Words to Action-Study of the Secretary General, United Nations, New York.

Note 6. Amnesty International, Human Rights Watch and the United Nations. (1999). Reports on the Abuse of Women in US Prisons. Retrieved May 5, 2011, from http://www.cfdp.ca/boje.htm

Note 7. Article 2.

Note 8. Article 4-c.

Note 9 . Article 1. 